第81回日本内科学会講演会

宿 題 報 告

高血王症の病態と予後*

九州大学医学部第二内科・国立循環器病センター病院

尾前 照雄

\title{
SPECIAL ARTICLE: PATHOPHYSIOLOGY AND OUTCOME OF HYPERTENSIVE SUBJECTS
}

Teruo OMAE, MD

Professor, the Second Department of Internal Medicine, Faculty of Medicine,

Kyushu University, Fukuoka and Director of Hospital,

National Cardiovascular Center, Suita, Osaka

\section{1.緒䡚}

高血王症患者の病態々予後は，高血王の基礎疾 患, 心血管障害の程度，合併する疾患によつて左 右される. 収縮期血圧，拡張期血圧とむ血王値の 高いすのほど，平均余命が一般に短いことがよく 知られているが，それは集団を比較した場合の成 績であつて，同一の血王群に属するものが必ずし む同一の運命をたどるとは限らない，高血王は心 血管病の最す重要なりスクファクターであるが, 脳卒中，心疾患，腎障害などと高血王とのかかわ りは一律に論じ難い問題を含んでいる，本報告で は，高血圧の病態の多様性，予後とそれに影響す る諸因子，心血管病のリスクファクターとしての 高血王の意義, 治療法の変遷, 降王薬治療の早期 にみられた心血管事故について述べ，最後に今後 の研究課題のなかで重要と考えられる事項に関し ての私見を述べる。

\section{2. 高血圧の基碟疾患}

高血王の基礎疾患（あるいは原因疾患）は，こ れをとり扱ら施設と研究対象集団によつて差があ る. 演者は教授就任以来 12 年間(昭和 46 年 58 年)

*本講演は 1984 年 4 月 2 日, 福岡市中央区天神 5 丁目 福岡市民会館大ホールにて行なわれた。
に九大第二内科教室に入院した抬張期性高血王

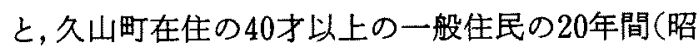
和36年～昭和56年）の剖検例について基礎疾患を 調查した。入院957例中本態性高血王は576例 $(60.2 \%)$ ，久山町131剖検例中のそれは126例 (96.2\%)であつた。のこりが 2 次性高血圧と判断 された２次性高血王のなかでは㷂性高血王の頻 度が最も高い(表 1 )。研究母集団によつて高血王 の成因, 病態，予後がいちじるしく異なることは， これらを論ずる場合に常に注意すべき点である.

\section{3. 高血圧の代謝性因子}

（1）電解質代謝とレニン・アンジオテンシン アルドステロン系

電解質代謝とレーン アンジオテンシン アル ドステロン系 (RAA系と略) はきわめて密接に関 連しているので, 一定のブロトコールにしたがつ てこれを検索した（図 1)。入院後 10 日間以上 $10 \mathrm{~g}$ 食塩食を与え，その間にアンジオテンシン I 変換 酵素阻害薬（カプトプリル25mg）を 1 回経口投与 して血圧の反応を観察したのち，採血，24時間蓄 尿を行ない，次いで負のNaバランスをるたらすた めにフロセミド $120 \mathrm{mg}$ の経口投与と，2g食塩食を 3 日間与えた。その間にアンジオテンシンII拮抗 
薬 ( ${ }^{1}$ sar- ${ }^{8}$ ile-angiotensin II, AIIA と略) $600 \mathrm{ng} / \mathrm{kg} /$ 分持続静注に対する血圧反応を観察し, 最終日に 採血，採尿を行なつた。採取した血液については， 血浆レンン活性 $(\mathrm{PRA})^{1) 2)}$, 血浆アルドステロン濃 度 $(\mathrm{PAC})^{3 / 4)}$ の測定, 尿については $\mathrm{Na}, \mathrm{K}$ 排泄量を 焰光光度計を用いて測定した。

プロトコールが守られているか否かのチェック なしには，RAA系の評価はできないので，まずそ

表 1. 高血圧の基碟疾患一抁張期性高血圧一

\begin{tabular}{|c|c|c|}
\hline & $\begin{array}{c}\text { 入院例 } \\
(\text { (昭和 } 46 \text { 年 } ＼mathrm{~ 昭 和 58 年) ~} \\
\end{array}$ & $\begin{array}{l}\text { 久山町 } \\
\text { (剖検例) }\end{array}$ \\
\hline 本態性高血王 & $576(60.2 \%)$ & $126(96.2 \%)$ \\
\hline 二次性高血王 & $381(39.8)$ & $5(3.8)$ \\
\hline 霄性高血王 & $301(31.5)$ & $4(3.1)$ \\
\hline 内分泌性高血压 & $61(6.4)$ & $1(0.7)$ \\
\hline その他の高血压 & $19(2.0)$ & $0(0)$ \\
\hline
\end{tabular}

抎張期血圧 $95 \mathrm{mmHg}$ 以上または降圧薬服用者

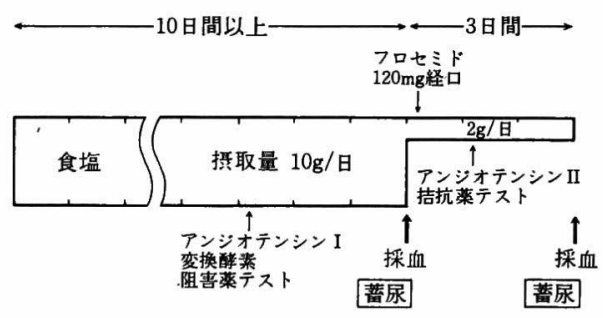

図 1. 脱塩プロトコール
の点を検討した。食塩 $10 \mathrm{~g}$ 食 ( $\mathrm{Na} 171 \mathrm{mEq})$ 下の 症例は423例であつたが, 尿中Na排泄量は22 427 $\mathrm{mEq} / \mathrm{d}(124 \pm 54 \mathrm{mEq} / \mathrm{d}$, 平均値士標準偏差)の分 布を示した。そこで，ほぼ平均値士標準偏差の範 囲を許容域とすると，312例（約75\%）がそれに該 当した。食塩 $2 g$ 食 ( $\mathrm{Na} 34 \mathrm{mEq}$ ) 下の症例につい ては, 尿中 $\mathrm{Na}$ 排泄量 $50 \mathrm{mEq} / \mathrm{d}$ 未満を許容域とす ると，251例中 215 例（約85\%）が該当した。両者 の許容域を満足したものは152例であつた. 以下に 示すすべての成績は, 尿中Na排泄量が許容域にあ るもののみについて得られたものである.

\section{i）基礎疾患別PRA, PAC, 血清 $\mathrm{Na}$ とK值}

$10 \mathrm{~g}$ 食塩食下臥位における基礎疾患別PRAにつ いてみると, 原発性アルドステロン症ではPRA低 值の傾向, 腎血管性高血圧では高値の傾向を示し, 両者は区別可能であるが，それぞれについては本 態性高血圧, その他の高血圧とをPRAによつて区 別することはできない（図 2).この条件下では PRAによつて基礎疾患をスクリーニングするこ との意味がきわめて少ないことを示している.

レニン分泌が最も刺激されたと考えられる $2 \mathrm{~g}$ 食塩食下立位のPRAについて同様の検討を行な らと, PRAがきわめて低値の場合は, 原発性フル ドステロン症が多く含まれる。しかし，原発性フ ルドステロン症でる，このような条件下ではPRA

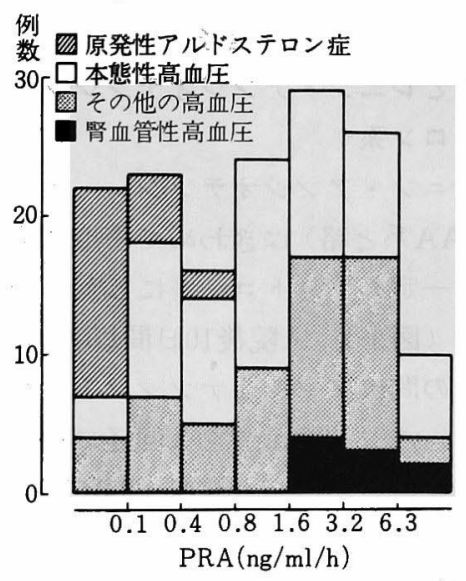

図 2，基礎疾患別PRA（食塩 10 g/日, 臥位)

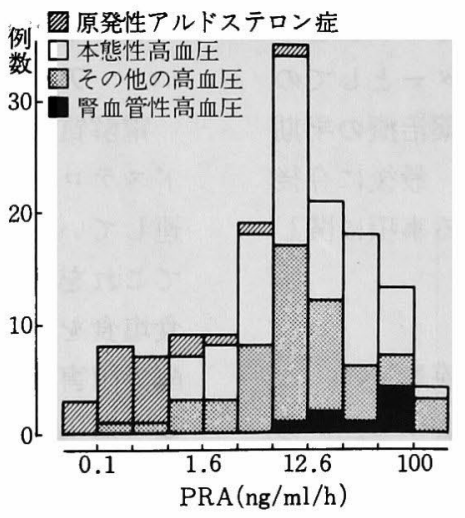

図 3 . 基礎疾患別PRA（食塩2 g/日, 立位)

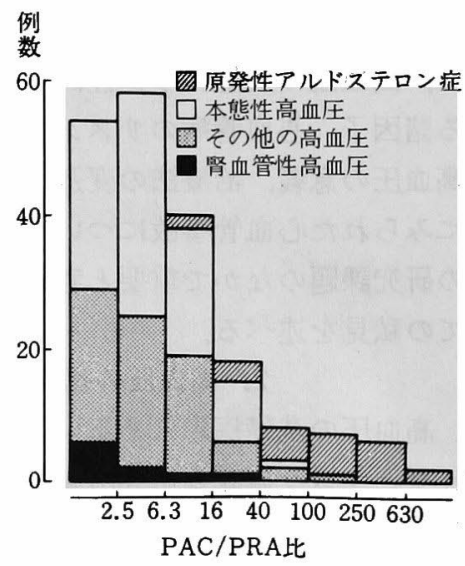

図 4. 基碗疾患別PAC/PRA比 （食塩 $2 \mathrm{~g} /$ 日, 立位) 
がかなり上昇する例がある，また，本態性高血圧， その他の高血圧ですPRAが高值を示す例が多く なり，腎血管性高血圧との区别が難しい、低レニ ン性本態性高血圧をこのようなレニン分泌刺激下 でむPRAが低值に止まる高血王と定義すれば，そ のような症例はきわめて少ないことが分かる。 PRA 0.8ng $/ \mathrm{ml}$ h以下とすれば，そのような症例 は皆無とすいえる（図 3 ）.

同様の条件下（食塩 $2 \mathrm{~g}$ 食立位）で基礎疾患別 PAC/PRA比をみると，これが高値のものほど原 発性アルドステロン症の頻度が高くなるが, 250倍 以下の場合は絶対的な診断基準とはならない４0 倍以下の場合は，各種の高血珐が入り混つている (図 4 ).

原発性アルドステロン症では血清 $\mathrm{K}$ 低値, $\mathrm{Na}$ 高 值傾向があるので，入院時の血清 $\mathrm{K} / \mathrm{Na}$ 比を各種

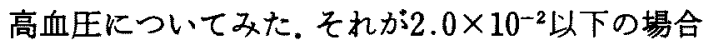
は全例が原発性アルドステロン症であつたが，そ れ以上では他の高血圧が混在する，腎血管性高血 圧は全例が2.5 3.5 $\times 10^{-2}$ の間にあり，原発性了 ルドステロン症とは 1 例を除いてはオーバラップ がなかつに（図 5).

ii）カプトプリルテスト

$10 \mathrm{~g}$ 食塩食下にカプトブリル25mg経口投与した

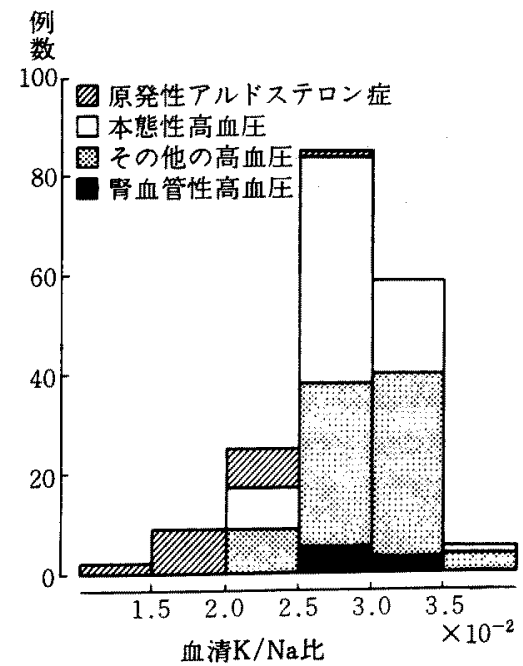

図 5.基礎涘患別血清 $\mathrm{K} / \mathrm{Na}$ 比（入院時）

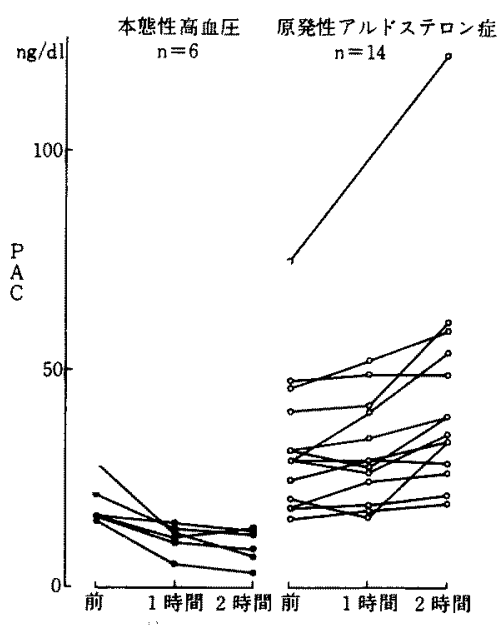

図6.カプトプリルテスト

表 2.カブトプリルテスト

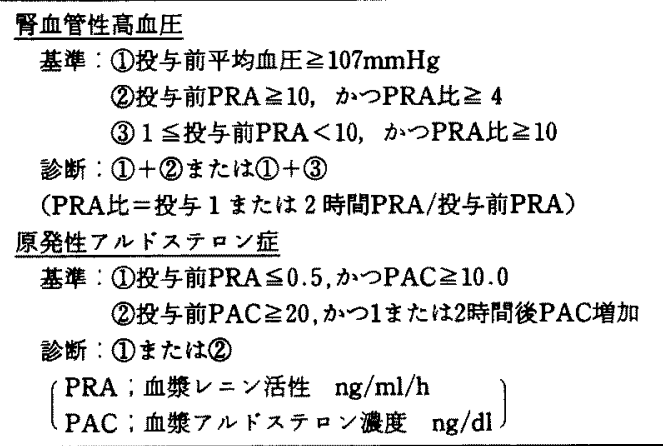

あとのPACを測定すると，本態性高血王では低下 するが，原発性アルドステロン症では不变または 増加し，投与 2 時間後のPACは両者の間に全く オーバラップがなくなつた（図6）.

そこで，腎血管性高血圧と原発性アルドステロ ン症のカプトプリルテストによる診断基準を表 2 のように定めた。

iii）罗血管性高血圧と原発性アルドステロン症 の各種検查法の診断率

高血珐患者についてテストした各種検查法の診 断能力を，それぞれ単一の検查值について評価し た，腎血管性高血王について，卧位PRA（食塩10 $\mathrm{g} /$ 日下) $3.2 \mathrm{ng} / \mathrm{ml} / \mathrm{h}$ 以上, 立位PRA（食塩 $2 \mathrm{~g} /$ 日 下) $50.0 \mathrm{ng} / \mathrm{ml} / \mathrm{h}$ 以上, AIIAテストによる平均血 
表 3．腎血管性高血王の診断率

\begin{tabular}{|c|c|c|c|c|}
\hline 畛 断 法 & 基 & $\mathbf{n}$ & スクリーニンク & 感度 \\
\hline 卧位PRA，食塩 $10 \mathrm{~g} / \mathrm{B}$ & $3.2 \mathrm{ng} / \mathrm{ml} / \mathrm{h}$ 以上 & 289 & $56 \%$ & $14 \%$ \\
\hline 立位PRA，食塩 $2 g$ /日 & $50.0 \mathrm{ng} / \mathrm{ml} / \mathrm{h}$ 以上 & 206 & 50 & 24 \\
\hline AII Aテスト & $10 \%$ 以上降压 & 188 & 78 & 33 \\
\hline カブトプリルテスト & & 89 & 90 & 100 \\
\hline
\end{tabular}

表 4，原発性アルドステロン症の診断率

\begin{tabular}{|c|c|c|c|c|}
\hline 凃 断 法 & 基 & $\mathrm{n}$ & スクリーニンク & 感度 \\
\hline 血清 $\mathrm{K}(\mathrm{mEq} / \mathrm{L})$ & 3.5 末満 & 184 & $95 \%$ & $59 \%$ \\
\hline 血清 $\mathrm{K} / \mathrm{Na}$ 比 & 0.025 末満 & 184 & 95 & 53 \\
\hline 臥位PRA，㖵塩 $10 \mathrm{~g} / 日$ & $0.4 \mathrm{ng} / \mathrm{ml} / \mathrm{h}$ 末满 & 289 & 91 & 57 \\
\hline 立位PRA，食塩 $2 \mathrm{~g} /$ 日 & $"$ & 205 & 48 & 91 \\
\hline 臥位PAC，食塩 $10 \mathrm{~g} /$ 日 & $40 \mathrm{ng} / \mathrm{dl}$ 以上 & 241 & 50 & 77 \\
\hline 立位PAC/PRA比，食塩 $2 \mathrm{~g} / \mathrm{G}$ & 40 以上 & 193 & 79 & 83 \\
\hline A II A デスト & $10 \%$ 以上昇王 & 188 & 90 & 50 \\
\hline カブトブリルテスト & & 89 & 100 & 94 \\
\hline
\end{tabular}

圧10\%以上の降圧, 前述のカプトプリルテスト陽 性をとりあげた。スクリーニング率はそれぞれ 56\%，50\%，78\%，90\%であつた。これに反して 感度は $14 \% ， 24 \% ， 33 \% ， 100 \%$ ，カプトプリル テスト以外はきわめて低かった(表 3).ちなみに， スクリーニングとは腎血管性高血圧全体のなかの 陽性率，感度はテスト全陽性者中の腎血管性高血 圧の頻度を意味する。すなわち，前者が高いこと は疑陰性率が低いこと，後者が高いことは疑陽性 率が低いことを意味する。

同様の評価を原発性アルドステロン症について 行なつた. スクリーニング $90 \%$ 以上の所見は血清 $\mathrm{K} 3.5 \mathrm{mEq} / l$ 末満, 血清 $\mathrm{K} / \mathrm{Na}$ 比 0.025 末満, 臥位 PRA（食塩 $10 \mathrm{~g} /$ 日下） $0.4 \mathrm{ng} / \mathrm{ml} / \mathrm{h}$ 末満, AIIAテ ストによる $10 \%$ 以上昇圧，カプトプリルテスト であつた，感度 $80 \%$ 以上所見は立位PRA（食塩 $2 \mathrm{~g} /$ 日下) $0.4 \mathrm{ng} / \mathrm{ml} / \mathrm{h}$ 末满, 立位PAC $/ \mathrm{PRA}$ 比(食 塩2g/日下)40以上，カプトプリルテストであつた (表 4 ).

\section{iv) PRA と缕器陣害}

良性本態性高血圧について，10g食塩食下に PRAを湘定し，それを高レニン，正レニン，低レ ニンの 3 群に分けて, 左心室肥大 (心電図), ST.

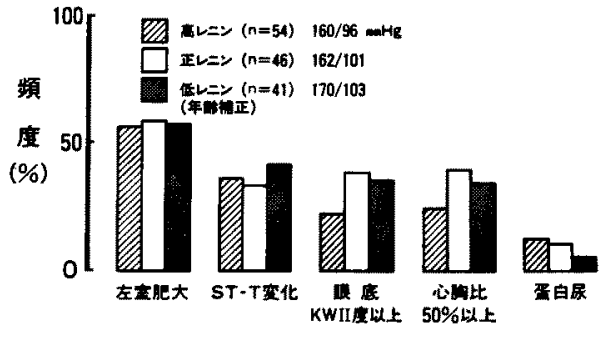

図 7. 本態性高血圧症のPRAと䁍器障害

T変化，眼底KWII以上，心拡大(心胸比 $\geqq 50 \%$ )， 蛋白尿の頻度を調べた。、いすれの所見についても 3 群間に差がなく，血圧值にも 3 群間に差はなか つた（因 7).

(2) 脱塩による血圧の変化

良性本態性高血圧54例について，前述のプロト コールによる脱塩操作時の平均血圧の変化を観察 した、脱塩前の値と等しい場合を 0 とし，脱塩後 の変化率をパーセントであらわすと, $-28 \%$ か ら+30\%までの範囲にばらついている（因 8 ). 10\%以上下降したものを降圧群，10\%以内の変動 を不変群とすると，前者10例，後者41例であつた．

降王群と不变群において，年令，血王の前值， 


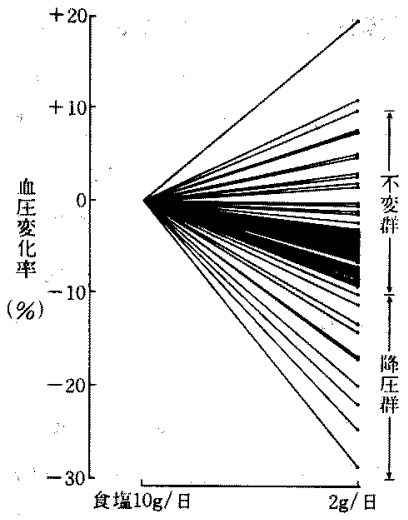

因 8，脱塩による血岖反応（本㿟性高血圧）

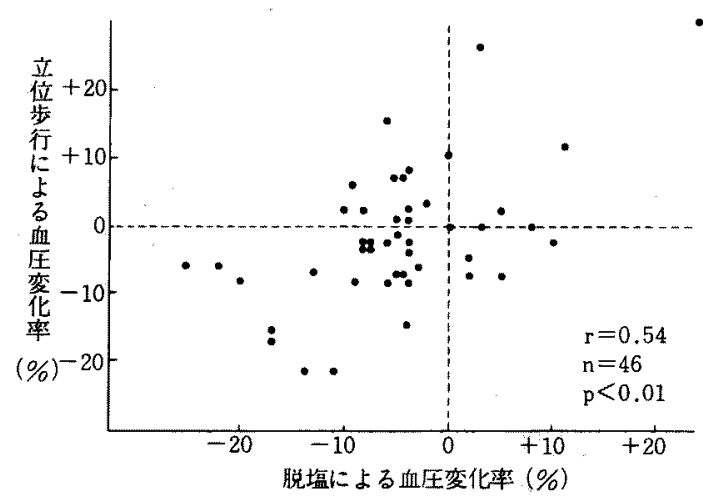

図 9.1 時間立位歩行時 ( $10 \mathrm{~g}$ 食塩下) の血圧変化と脱 塩による血圧変化の相関

脈拍数, 臓器障害の程度, 脱塩前後のPRA, 尿中 $\mathrm{Na}$ 排泄量, 血清クレアチニン值, クレアチニン・ クリアランス値，Kクリアランス値に差は認めら れていない。

脱塩による血王変化率と $10 \mathrm{~g}$ 食塩食下 1 時間立 位歩行による血圧変化率の間には有意の正相関 $(\mathrm{r}=0.564, \mathrm{p}<0.01 ）$ がみられた（図 9)，すなわ ち，脱塩後血圧の下がるものは，脱塩前 1 時間步 行後の血圧が歩行前よりる下がりやすかつたこと を意味する。脈拍数の変化には降圧群と不変群の 間に差はみられていない。この現象の機序は明ら かでないが，脱塩ないし歩行時の体液分布の変化 に関連した現象かる知れないと考えている。
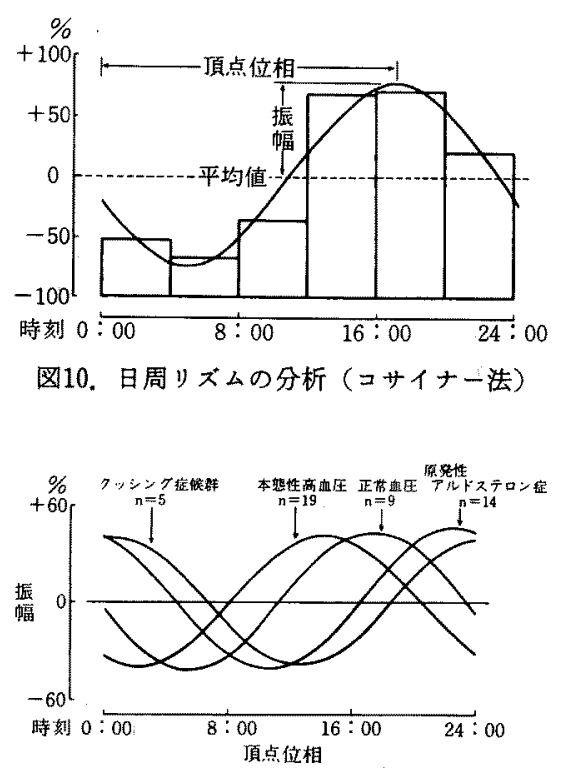

図11，属中Na排泄の日周リズム（食塩 $10 \mathrm{~g} /$ 日）

（3）尿中Na排泄の日周リズム

生体の機能にはリズムがあり，血圧, RAA系な どの内分泌機能,腎機能などもその例外ではない。

日周リズムの分析は, \%変化率に対して余弦関 数を最小自乗法を用いて回帰分析するコサイナー 法5)6)を用いた(図10)。平均值からの振幅と，機能 のピークに達する時間を頂点位相としてあらわ す.

クッシング症候群，本態性高血圧，正常血圧， 原発性アルドステロン症に招ける尿中Na排泄の 日周リズムをみると，基礎疾患による差が明らか に認められる，正常血圧対照者の頂点位相は午後 5 時付近にあるが，本態性高血王では約 3 時間早 くなつている。原発性アルドステロン症とクッシ ング症候群では 5〜6時間和くれて午後11時付近 にそれがあらわれている778)(図11)，この成績は原 発性アルドステロン症などでよく知られている夜 間多尿の現象によく符合している。このNa排泄の リズムは，PRA，PACの日周リズムとは関連がな

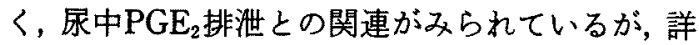
細は今後の検討にまたねばならない。

原発性フルドステロン症では，副腎腺腫摘出後 


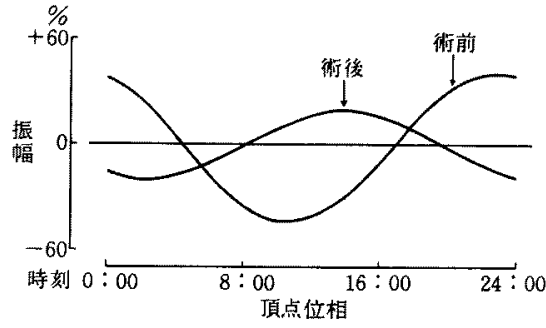

図12、原発性アルドステロン症 $(n=14)$ の術前・術後 に打ける尿中Na非溇の日周リズム（食塩 $10 \mathrm{~g} /$ 日）

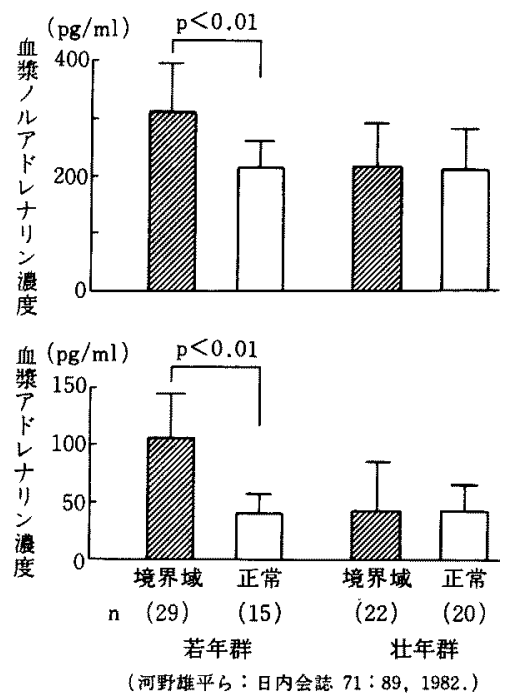

因13、境界域高血压に括ける血暴カテコラミン濃度

は，この尿中Na排泄リズムの変調は正常化した量 (図12)。

（4）境界域高血圧と血浆カテコラミン

若年群の境界域高血圧29名(平均年令22才)，正 常血王15名(平均年令21才), 壮年群ではそれぞれ 22 名（平均年令 50 才），20名（平均年令51才）につ いて血浆カテュラミン濃度を測定した。

ノルアドレナリン, アドレナリン濃度とも, 若 年群の境界域高血圧で有意の高値を示した ${ }^{9)}$ (困 13）。拍数す有意に増加して扣り，若年群境界域 高血圧では交感神経・副腎機能の立進があると考 えられる，壮年群境界域高血厈ではそれが認めら れないので, 境界域高血正の病因, 病態生理は若 年群と壮年群において差があると考えられる。
若年群境界域高血王々正常血珐者について， ， ルナドレナリン静注に対する昇环反応，イソブロ テレノールによる心拍数増加の程度は，いずれも 血浆ノルナドレナリン濃度と負の相関がみられ た。このことは，心血管反応性は血浆ノルアドレ ナリン濃度と関連したもので，それ自体の変化が 血圧上昇に関与していないことを示唆してい $3^{10)}$.

\section{4. 高血圧患者の予後}

追跡調查対象者は過去 10 年間に当科に入院した 1647例（男1022，女625）で, 平均年令は45.6土15.9 才，生死判明者数 1593 例(96.7\%)，平均追跡期間 $6.4 \pm 2.8$ 年であつた．対象疾患は，すべての高血 王(病歴あるものを含む), 糖尿病, 僈性系球体腎 炎，腎不全とし，後 3 者については高血圧の有無 に関係なく全例を採択した。

生死判明者1593例中，予後に影響すると考えら れる疾患 (悪性腫場，肝硬变症など) 552 例，脳卒 中, 心疾患, 大動脈疾患, 血清クレアチニン値 $2 \mathrm{mg} /$ $\mathrm{d} 1$ 以上の腎機能障害例231例を除外して，810例を 予後調査対象者とした（図14）。

基礎疾患別の予後調查成䋶を表 5 に示す．粗死 亡率についてみると，本態性高血圧7.6\%に比べ， 糖疗病十高血圧例 $32.1 \%$ で有意に高率である。糖 尿病＋正常血圧例 $10.5 \%$, 二次性高血王 $9.4 \%$, 腎 炎十高血王 $3.4 \%$ ，その他3.2\%である。糖尿病十 高血王を，本態性高血圧に糖尿病（耐糖能異常） が合併したと判断されるものと，糖尿病の診断と 治療を主たる目的に入院し，高血圧の合併が認め られたものの 2 群に分けてみると, 前者が $25.9 \%$,

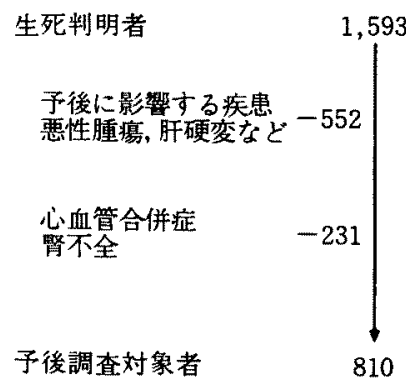

国14。予後調查 
表 5. 基礎疾患別予後調査成楮責

\begin{tabular}{|c|c|c|}
\hline & 例 数 & 粗死亡率 \\
\hline 本憄性高血王 & 184 & $7.6 \%$ \\
\hline 糖尿病十高血圧 & 78 & $32.1^{* *}$ \\
\hline (本熊性高血压 & 27 & $25.9^{* *}$ \\
\hline 高血王 & 51 & $35.3^{* *}$ \\
\hline 糖䐂病＋正常血生 & 114 & 10.5 \\
\hline 二次性高血压 & 64 & 9.4 \\
\hline 腎资十高血王 & 29 & 3.4 \\
\hline その他 & 341 & 3.2 \\
\hline 計 & 810 & 8.5 \\
\hline
\end{tabular}

** p $<0.01$ vs. 本熊性高血圧

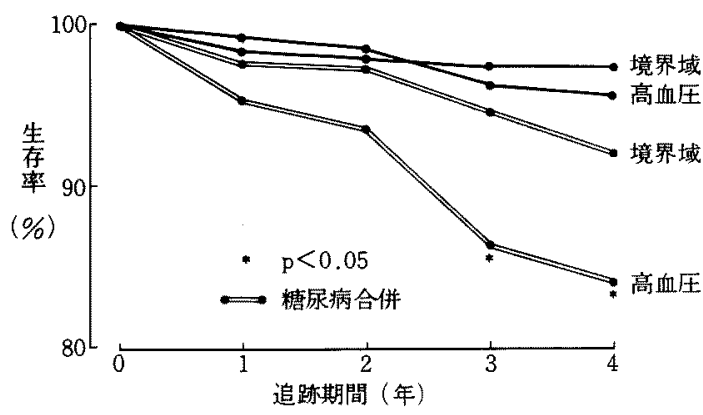

図15，糖尿病の有無による血殴群別生存率一全死亡一

啳者が35.3\%でいずれも有意に高率であつた。

糖尿病の有無による 4 年間の血王群別生存率を 図15に示す。追跡 3 年後から糖尿病十高血圧の生 存率が有意に低くなつており，糖尿病十境界域高 血圧も，高血王群のみの群より低い生存率を示し ている。

糖尿病合併の有無による高血圧の死因別粗死亡 率を表 6 に示した。死因はアンケート調査にもと つ゚く死亡猃断書，通院または入院死亡例は，われ われ自身あるいは当該病院の医師の診断によるも のである.脳卒中死は，糖尿病の有無によつてか わらず，心筇梗塞，心血管障害死，腎不全，その 他による死亡は糖尿病合併例に有意に高頻度であ つた. 全体の死亡頻度も本態性高血王 $7.4 \%$, 高血 王十糖尿病 $34.6 \%$ で 5 倍近いひらきがあつた。追 跡開始前の血王値は両群間に差がなく，心電図の 左心室肥大所見の頻度は糖尿病非合併例に高頻 度，蛋白尿は糖尿病合併例に高頻度であつた。
表 6. 糖尿病合併例の死因別粗死亡率 (予後調査対象者)

\begin{tabular}{|c|c|c|}
\hline & $\begin{array}{c}\text { 本態性高血厈 } \\
\mathrm{n}=184\end{array}$ & $\begin{array}{c}\text { 高血圧+糖病病 } \\
n=51\end{array}$ \\
\hline 脳出血 & $2.1 \%$ & $1.9 \%$ \\
\hline 脳梗寨 & 1.1 & 1.9 \\
\hline 脳血管障害 計 & 3.7 & 3.8 \\
\hline 心筋梗塞 & 0.0 & $5.8^{* *}$ \\
\hline 心・血管障害 計 & 0.5 & $9.6^{* *}$ \\
\hline 紧不全 & 0.0 & $7.7 * *$ \\
\hline 覀性新生物 & 1.1 & 3.8 \\
\hline その他 & 2.1 & $9.7 * *$ \\
\hline 計 & 7.4 & $34.6^{* *}$ \\
\hline
\end{tabular}

表 7. 蛋白尿の有無による糦尿病の予後

\begin{tabular}{|c|c|c|}
\hline \multirow[b]{2}{*}{ 死＼cjkstart因 } & \multicolumn{2}{|c|}{ 蛋白尿 } \\
\hline & $\mathrm{n}=182$ & $\begin{array}{c}(+) \\
\mathrm{n}=56\end{array}$ \\
\hline 琏血管障要 & $7(3.8 \%)$ & $2(3.6 \%)$ \\
\hline 心・血管障害 & $3(1.6)$ & $5(8.9)^{*}$ \\
\hline 腎不全 & $2(1.1)$ & $6(10.7)^{* *}$ \\
\hline その地 & $13(7.1)$ & $5(8.9)$ \\
\hline 計 & $25(13.7)$ & $18(32.1)^{* *}$ \\
\hline
\end{tabular}

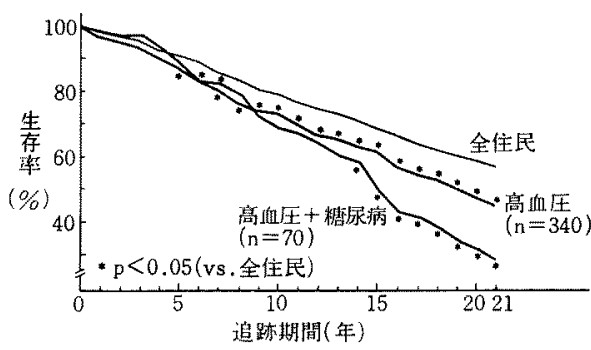

图16. 高血圧および糖杘病合併の有無による生存率 (性・年令階級補正) 久山町，男女，21年間

高血王の有無に関係なく，糖尿病の予後を蛋白 尿の有無によつて調查した。蛋白尿 $(+)$ 例は $(一)$ 例に比べて全死亡の頻度が 2 倍以上高く, 疾患別 にみると脳卒中はかわらず，心，血管障害と腎不 全死が明らかに高率であつた(表 7 )。高血圧十糖 尿病の生命の予後を不良にしている主な要因は, 心・血管疾患と腎不全であつたといえる。 
40才以上の久山町追跡対象者についてみると， 21 年間の追跡調查成績は図16のようである。性と 年令階級は補正してある.全住民の生存率に比べ， 高血压群, 高血圧＋糖尿病群の順に低下している. 追跡 5 年後玉では 3 群間に有意の差がないが，そ れ以後に差が出ている. 入院例よりる差が顕著で ないのは，久山町例では多くが軽症例であるため と考えられる。久山町例では腎死例はこれまで経 験されていない。

\section{5. 心血管病のリスクファクター}

高血圧が心血管病のきわめて重要なリスクファ クターであることについては異論がないしかし， 高血圧以外にリスファクターとなり得る種々の因 子がある，高血圧とこれらの因子はしばしば相加 的あるいは相乗的に作用するすのと考克る，抑制 ないし保護因子の存在す否定はできない（図17）.

糖疗病や高脂血症などは促進因子としての代表 的なものであろ5，日本人と米国人では高血圧の 頻度はそれはどかわらないのに，日本人に脳卒中 が多く心筇梗塞が少ないのはなぜか，女性よりも 男性に心血管病のリスクが高いのはなぜか，原発 性アルドステロソ症では心血管病が比較的蛒こり にくいのはなぜか,などの問題はこれらに関連し た事項である。人種差, 遺伝要因の差もこれに関 連している可能性がある。 また，脳卒中，虚血性 心蔵病，腎不全などと高血圧との関連を一律に論 じ難いことも周知のことであろう。

以下. 久山町研究で得られた幾つかの成績を述 べる11). 久山町研究は昭和36年 (1961年)に開始さ れ20年以上を経過したが，この間に生活環境と医 療括よび健康管理態勢はいちじるしく変化した。 そこで13年の間隔をおいて二つの追跡集団を設定 した．第 1 集団は昭和 36 年に設立した 40 才以上の

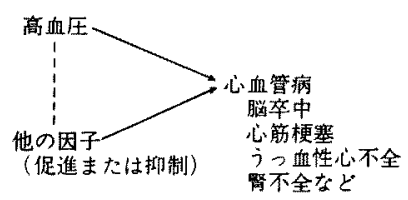

図17，高血圧と心血管病
表 8.久山町における 2 追跡集団

\begin{tabular}{|c|c|c|}
\hline 対象者数 & 第 1 集団 & 第 2 箖団 \\
\hline 対象者数 & 1621 & 2053 \\
\hline 男 & $\Gamma 707$ & $\Gamma^{862}$ \\
\hline 女 & L $\quad 914$ & L 1191 \\
\hline 平均年令(才) & & \\
\hline 男 & 55.5 & 56.5 \\
\hline 女 & 56.9 & 58.3 \\
\hline 追跡期間 & $1961-1968$ & $1974-1981$ \\
\hline 剖検 率(\%) & 78.1 & 85.0 \\
\hline
\end{tabular}

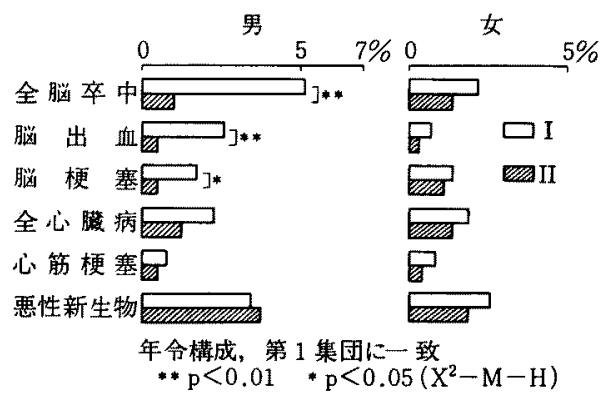

図18. 主要死因別頻度の比較一久山町 2 集団

男女住民1621名，第 2 集団は昭和49年（1974年） に設定した2053名である。それぞれを 7 年間追跡 した．各集団の性別，年令別構成はほとんどかわ らず，死亡者の剖検率はそれぞれ78.1\%，85.0\% である(表 8 )。

第 1 , 第 2 集団の主要死因別頻度を図18に示す。 第 2 集団に颃いては，第 1 集団に比べ，男の脳卒 中は約 5 分の 1 , 女の脳卒中す減つている，男で は脳出血死, 脳梗塞死とも有意に減つている。心 臓病による死亡は減少傾向にあるが，有意の差は ない，悪性腫場死はほとんど不変といつてよい。 第 2 集団では, 男女とも死亡の第 1 位は悪性腫煌, 第 2 位は心臓病，第 3 位は脳卒中となつている. 発症頻度でみても脳卒中のみが有意に減少してい る.

循環器疾患のリスクとしてあげられている因子 の頻度を両群間で比較した。男では, 高血圧の頻 度が27\%から19\%へ，心電図の左心室肥大所見( ネソタコードIII-1）の頻度が22\%から14\%に有意 


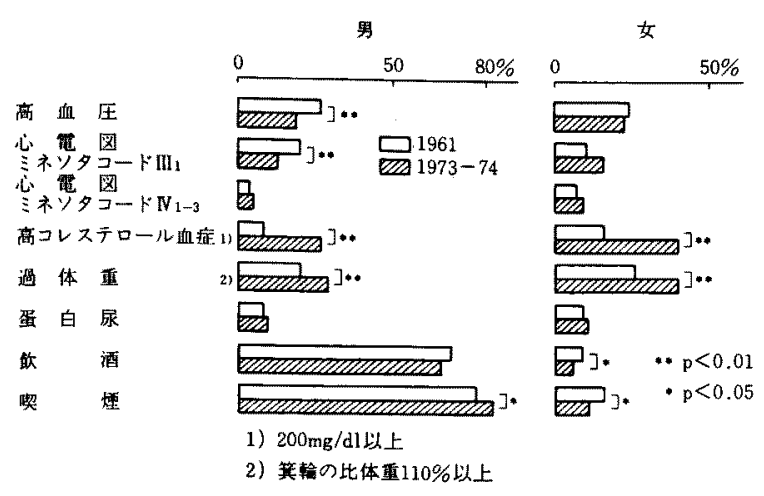

図19. 循瓖器疾患危険因子の頻度の比較一久山町 2 集 団

に減少した。一方，血清棇コレステロール值200 $\mathrm{mg} / \mathrm{dl}$ 以上の頻度は $7 \%$ から $26 \%$ に増加し，過体 重（筫輪比体重 $110 \%$ 以上）の頻度も14\%から $28 \%$ に増加していた，高コレステロール血症と過体重 の頻度は女についても第 2 集団では有意に増加し ていた，飲酒，笑煙習慣は女では第 2 集団に执い て減つているが，男では減つていない(図19)。こ の成績は, 高血圧と左心室肥大有所見者の減少之 栄養状態の改善が脳卒中の減少に結びついている 可能性を示している.

高血圧とアテローム硬化の程度との関連を大動 脈, 脳底部動脈, 冠動脈について検討した. 大動 脈之脳底部動脈に関しては, 久山町研究の初期の 10年間の約350剖検例について, 動脈硬化度(Gore 指数）と生前の血圧値との関連をみた．高血圧例 は正常血圧例に比べ，大動脈ではほぼ10１5年， 脳底部動脈ではは注20年早期に硬化が進行してい $た^{12) 13)}$.

冠動脈に関しては, 最近10年間の約250剖検例に ついて，3本の冠動脈㹟窄の程度を一定の方式に よつて codeし, その合計を狭窄度として生前の血 王值との関連をみた。払張期性高血王, 収縮期性 高血生とも正常血圧例に比べると，狭窄度が強く なつていた．扗張期性高血俚についてはいずれの 年令階級でも，収縮期高血王では60才台と70才台 に拉いて正常血圧例との差が有意であつた。冠動 脈硬化（狭窄度）の危険因子を重回帰分析で検討
表 9. 脳梗塞, 心筋梗塞の危険因子一多重口ジ ティック回帰分析, 久山町

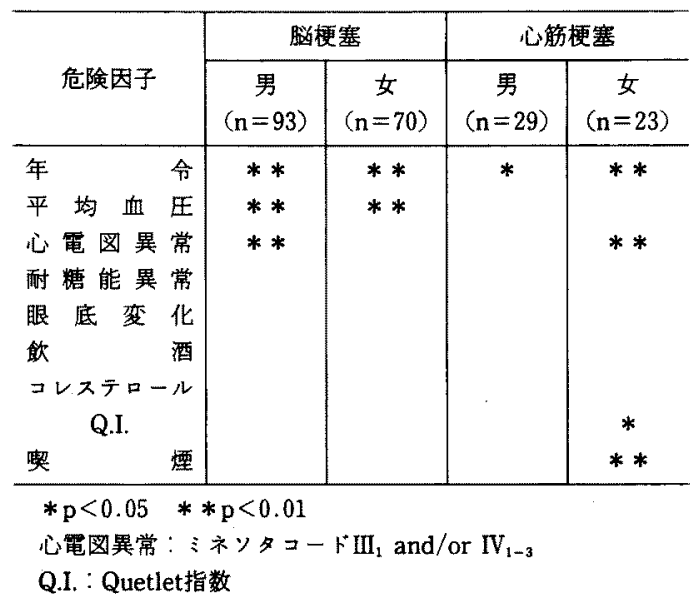

すると, 有意の正の関与としてとり上げられたも のは, 死亡時年令, 血圧, 血清コレステロール值, 性 (男>女)，Quetlet指数であつた，领酒習慣は有 意の負の関与, 啾煙習慣の関与は有意水準に達し ていない:14).

久山町研究の追跡調查 20 年間の成績から, 脳梗 塞と心筋梗塞の危険因子を多重ロジステイック回 帰分析によつて解析した，有意水準に達したもの のみをとりあげると，脳梗塞に関しては男では年 令，平均血圧，心電図異常，女では年令と平均血 王であつた。筇梗塞に関しては男では年令のみ， 女では年令，心電図異常，Quetlet指数，契煙であ つた(表 9). 血清総コレステロール值は冠動脈硬 化（狭窄度）には有意に関与している成績であつ たが，心筋梗塞に関しては男女とも有意に関与し ている成績は得られなかつた。 また，男女とも， 血王が心筇梗塞の有意の危険因子としてとりあげ られていない，これらの点に関しては，さらに心 筋梗塞の症例数がふえた時点での検討がのぞまれ る.

\section{6. 悪性高血圧症の病態と予後}

われわれの教室に 12 年間（昭和 $46 － 58$ 年）に入 院した KW III〜IV群の悪性ないし重症高血圧は 69例で，年令は19６0才（39.2土10.6才），男 $48 ，$ 女21例，KW III 24, IV 45例であった。 
表10，悪性高血圧症の基碄疾患

\begin{tabular}{|c|c|c|}
\hline & \multicolumn{2}{|c|}{ （昭 $46 \sim 58$ 年，九大第二内科) } \\
\hline 本態性高血王 & 33 & $(47.8 \%)$ \\
\hline 慢性系球体督资 & 26 & $(37.7)$ \\
\hline その他の腎䂏患 & 6 & $(8.7)$ \\
\hline 慢性霍血堅资 & 2 & \\
\hline 水腎症 & 1 & \\
\hline 多発性腎杯㽞室 & 1 & \\
\hline 督動脈㹟窄 & 1 & \\
\hline 焣動脈瘤 & 1 & \\
\hline 分類不能 & 4 & $(5.8)$ \\
\hline 計 & 69 & \\
\hline
\end{tabular}

基礎疾患は，本態性高血王33(47.8\%)，慢性系 球体腎炎 $26(37.7 \%)$ ， その他の腎疾患 $6(8.7 \%)$, 分類不能としたもの 4 （5.8\%）であつた（表10）。

悪性高血圧症では, 眼底に出血, 軟性白斑をは じめ網膜あるいは乳頭の浮腫がみられることが通 例である.本症の脳代謝異常の有無を知る目的で, 髄液乳酸值を測定すると，本症では正常血圧，良 性高血圧例に比べて有意に高值を示すことがみら れている.正常血王 $1.44 \pm 0.04$, 良性高血王 $1.50 \pm$ 0.05 , 熏性高血王 $1.90 \pm 0.10 \mathrm{mM} / l$ であつた ${ }^{15)}$.こ の所見は本症で脳の嫌気性解離の充進を示すもの である。

症例数の多い本態性高血王と慢性系球体腎炎を 基礎疾患とする本症の病態を比較すると，両者の 間にかなりはつきりした差がみられる。前者には レニン・アンジオテンシン系の関与が証明される が，後者にはそれが証明されない．前者ではPRA と平均血圧の間に有意の正相関があるが，後者に はそれがない(図20)。またアンジオテンシンII拮 抗薬 $600 \mathrm{ng} / \mathrm{kg} /$ 分， 30 分間接続注入によつて前者 の血圧は下降するが，後者ではそれがみとめられ なからた（図21）。

治療後の腎機能の経過も，両者では異なつてい た. 本態性高血圧では降王治療によつて腎機能(血 清クレアチニン値）はむしろ改善するものが多く 認められたが，慢性系球体腎炎の場合は腎機能障 害が進行し，比較的早期に血液透析に移行したも のが多い. 1 年以内に過半数が透析に移行した(図 22).この所見は, 本態性高血圧を基礎疾患とする

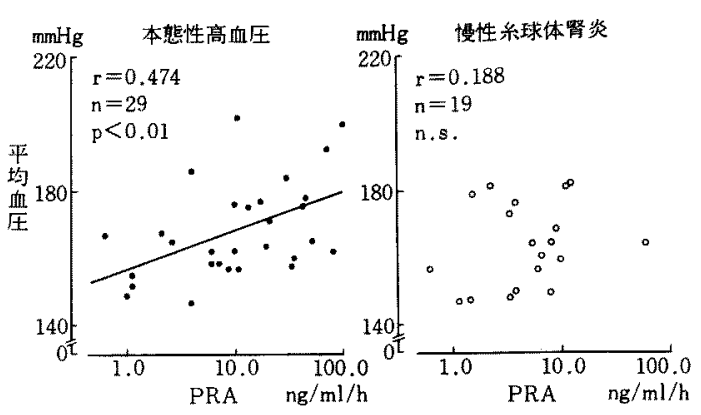

図20. 瑟性高血圧症一治療前平均血王とPRA一
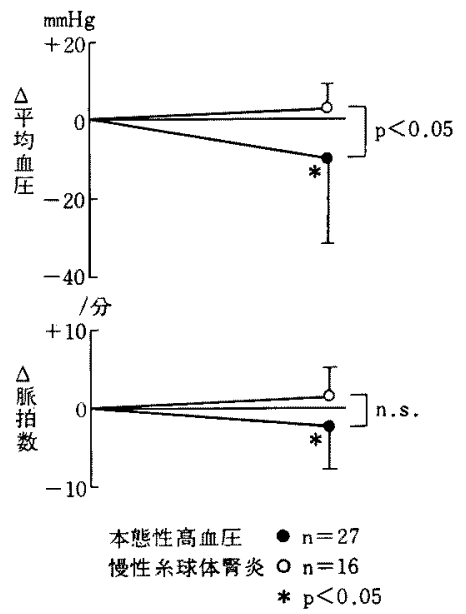

図21. 覀性高血王症一アンジオテンシンII拮抗薬に対 する反応一 $(600 \mathrm{ng} / \mathrm{kg} /$ 分， 30 分間持続注入 $)$

悪性高血圧症例では，血圧上昇と腎血管れん縮 ーレニン分泌の間に悪循環が成立していることを 示唆するが，慢性系球体腎炎の場合はそれが注と んど認められないためと考觉る。

5 年間追跡した悪性高血圧症の生命の予後は, 近年著明に好転し，5年生存率30例中26例 (86.7\%) であつた（図23）。ち半数以上は維持 透析患者であるが，これらわれわれのとり扱つた 症例は慢性系球体腎炎を多く含むためである。死 亡した 4 例 (13.3\%) はすべて本態性高血圧例で, 血液透析で生命を維持する限り，生命の予後は慢 性系球体腎炎の方がより良好といえるだろう。こ のように，治療法の進歩に伴う予後の好転といら 立場からいえば，本症に「悪性」の名を冠して呼 


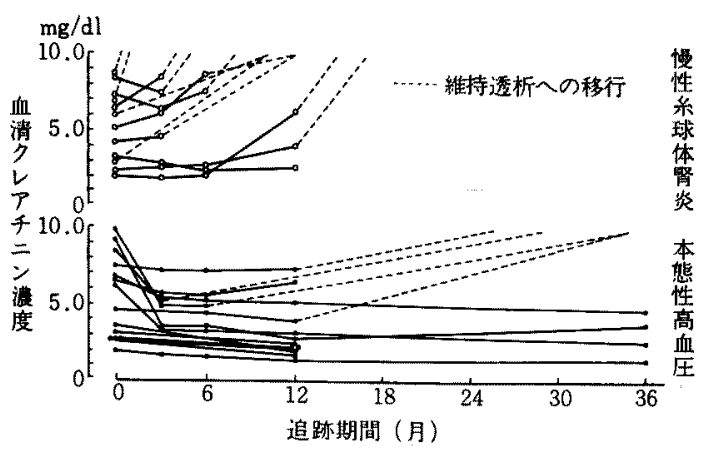

図22. 悪性高血压㱏一治療後の腎機能の経過一(治療 前血清クレアチニン濃度 : $2.0 \sim 10.0 \mathrm{mg} / \mathrm{dl}$ )

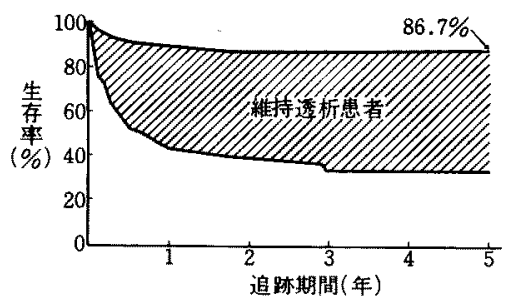

図23，悪性高血王症の予後(30例)（九大第二内科，昭 和 46 年 6 月～昭和 58 年 3 月)

ぶことの妥当性に疑問をお゙ぼるる時代になつた。

\section{7. 治療法の变遏}

近年，降王薬の開発がすすみ，作用機序を異に する種々の薬剤が治療に用いられるようになつ た。それぞれの薬剤の適応と効果については，固 定的な評価は今日必ずしも与えられていない，

われわれの教室に拈ける高血圧再来で過去12年 間に使用してきた薬剤の変遷を調查した。サイア ザイド系を主体とする利尿薬の使用頻度が最も高 く，常に $50 \%$ を超支ている。昭和 49 年以降は $\beta$ また は $\alpha$ 遮断薬の使用頻度が増加し, 昭和58年にはこ れも50\%を超えた。それに次いで近年は血管拡張 薬(主としてヒドララシン)，あるいはCa拮抗薬が 約30\%ないしそれ以上の頻度で使用されている.

レセルピン， $\alpha$-メチルドパなどの交感神経抑制 薬，交感神経遮断薬の使用頻度はそれに次ぎ，昭 和55年以降はアンシオテンシン I 変換酵素阻害薬 が使用されはじめている，血珐のコントロールは 近年よくなつている(図24)，使用薬剤の種類と頻

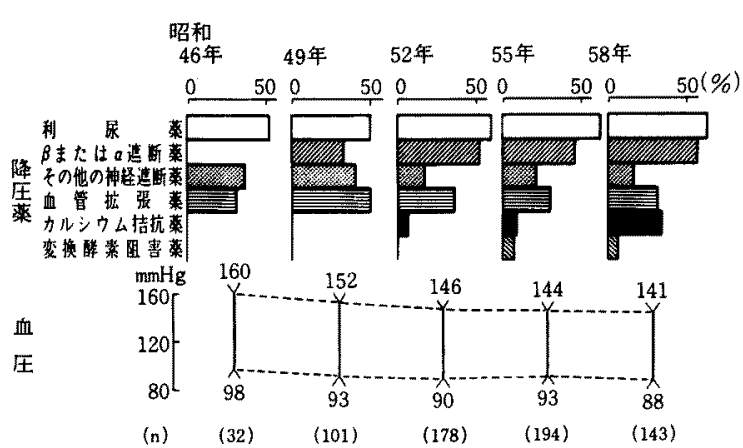

図24，治寮法の変䙴（九大第二内科再来）

度には施設による差がかなり大と考完られるが， 参考までにわれわれの成績を示した。

\section{8. 降圧治㫫中の事故}

本来，降圧治療は心血管事故の発生を予防する 目的で行なわれるが，降圧によつて臓器組織の血 液灌流が低下するために，脳，心，堅に虚血がお こり，そのために脳梗塞，虚血性心臟病が誘発さ れたり，腎不全の増悪がおこることがあり得る。 これは，降王療法の目的に反する本末顛倒ともい らべき偶発症であるが，われわれの経験した若干 の症例を提示する．このような事故はむしろ稀で はあるが, 高令者, 動脈硬化進行例などではこの ような事故の抗こり得る可能性を考虑し，降王療 法は慎重に行なう必要があると考学る。

因25は，降王療法開始後早期に脳梗塞を発症し た例である ${ }^{16)}$.44才の女性で悪性高血圧のために 入院した. 入院時収縮期血圧 $200 \mathrm{mmHg}$ 以上, 拡張 期血压 $130 \mathrm{mmHg}$ 以上で乳頭浮尰を認めた。 カプ トプリル（フンシオテンシン変換酵素阻害薬）は このような例にしばしば速効性に作用するので, その $75 \mathrm{mg} \rightarrow 100 \mathrm{mg}$ を経口投与した，血圧は速やか に正常血王近くまでコントロールされたが，3日 目に両側視力障害を訴え, 同時に両側の深部反射 穴進に気付いた。眼底には所見の変化がなく視力 障害の原因は不明であつた。搪張期血王が100 mmHgを超えるので, 降圧薬をブロプラノロー ル,ヒドララジンに変更し, 網膜と脳の浮腫性変 化を疑つてデキサメサゾンの投与を行なつた。 そ 


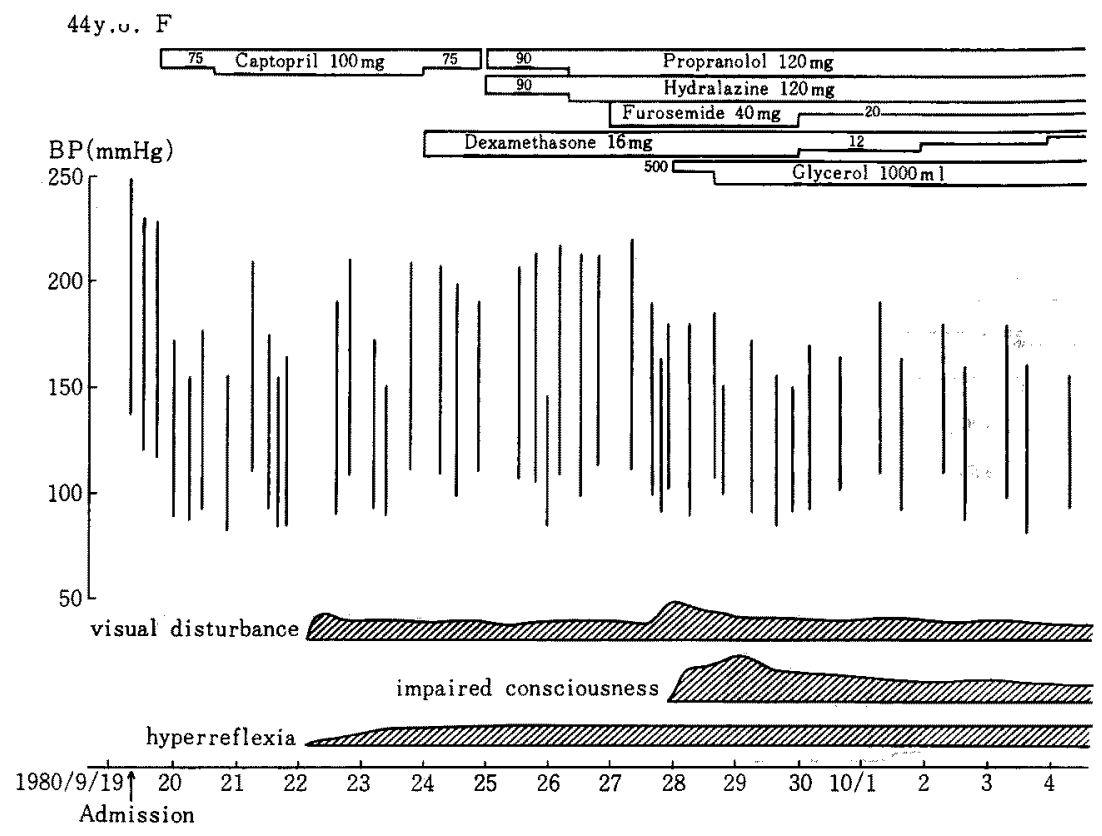

図25. 降王療法開始早期に脳梗塞を発症した症例

の数日後に, 再び視力障害の増悪と意識障害が加 わつたため，頭部CT検查を行なつたところ，両側 後頭葉と小腷に大きな梗塞巣の存在が確認され た．脳血管写では血管系に異常所見がなかつた。 本例は，それまでこのような症状は全くなく，血 管系にも異常所見のないことから，降圧療法に伴 ら脳循環調節機序の変調が脳虚血を招来したもの と推定される，高血王例では，脳循環自動調節の はたらく血圧の闘值が高いレベルにセットされて いるため，脳循環の保持が降压に対応できなかつ たためかも知れない，しかし，本症例では血王が 下りすぎとは必ずしも考えられないので，あらか じめそれを予知することはきわめて困難ではない かと考える。

図26は降王䒚使用の初期に心筋梗塞を誘発した 例である．65才，女性で高血圧と心不全のため入 院した。はじめジ゚キシンを用いていたが，血厈 が高いため利尿薬であるトリパマイド15mg（1 錠)を併用した。それによつて血圧は下降したが， 数日後悪心呕吐が出現，その 3 日後に発汗と胸痛 が抗こり，心電図上ST上昇，血清GOT, LDH上昇
があり，心筋梗塞の発症が確認された，本症例は 利尿薬投与 1 週間後に心筋梗塞が発症したが，そ の発症に利尿薬投与一降圧が無関係ではなかつた と考光られる，悪心呕吐や利尿に伴う循環血液量 の减少，血液粘稠度の増加などは，虚血発作の引 き金になり得るものと考光る、リスクの少ない症 例の場合には，勿論このようなことは括こり得な いであろらが，リスクの高い症例の場合は，降王 療法はより慎重に行ならべきすと考える。

図27は，堅機能障害例に過量の利尿薬が投与さ れたために著明な留機能低下を来した症例であ る. 45才，女性．BUN 30，血清クレアチニン1.5 $\mathrm{mg} / \mathrm{dl}$ の症例に, フロセミド, サイクロペンチアジ ド，ヒドララジン，プロプラノロールが投与され た. 約 9 カ月後BUN 50 , 血清クレアチニン $5 \mathrm{mg} /$ dl以上に上昇し，全身状態が悪化したために，その 評価のために入院した，血清蛋白濃度の上年，脈 压の減少は脱水の存在を示唆している.入院後す べての薬率を中止して経過を観察したところ，約 1 週間後に血清蛋白濃度の正常化，BUN，血清ク レアチニン值は著明に低下し，全身状態も著しく 


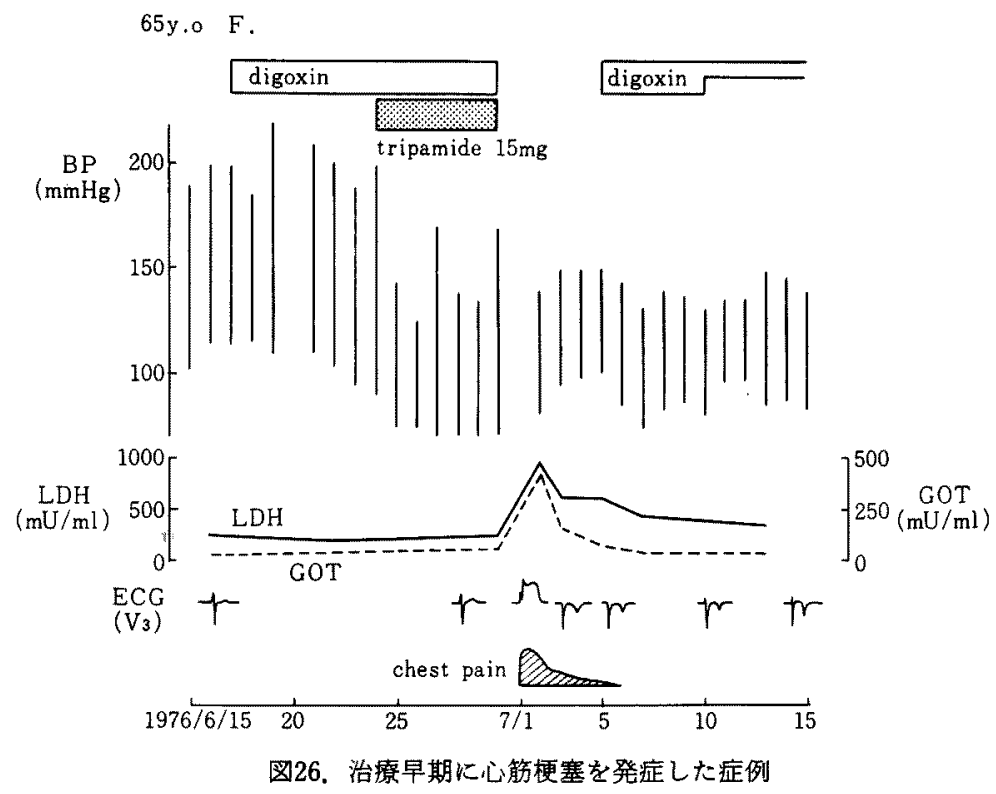

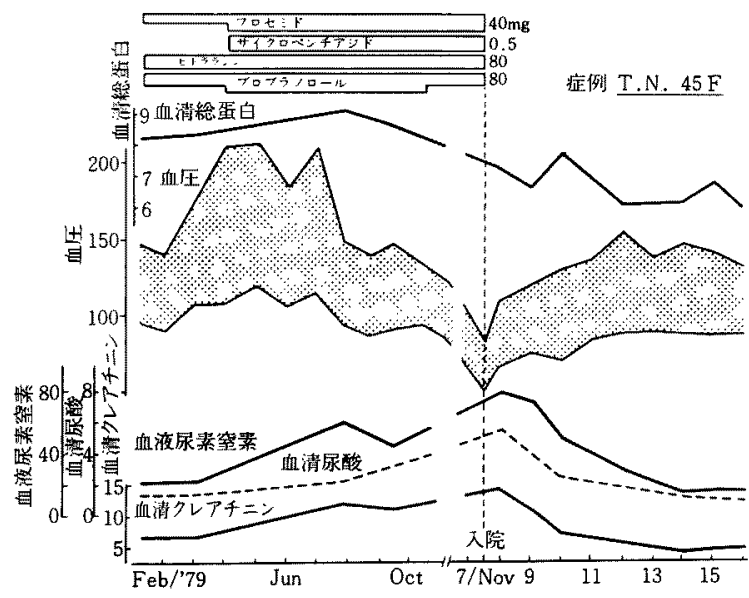

図27。利烁薬投与が腎機能を著明に悪化させた症例

改善された，本例は，近い将来透析療法の適応と なるのではないかとのことで，その評価のために 入院した症例であるが，医原性の腎不全症例とも いえる，近年，類似の症例にまれならず遭遇する ので，腎機能低下例にはサイアザイド系利尿薬の 投与は禁忌とす心゙きである。

\section{9. 結 語}

以上，九大第二内科教室に持けるわれわれの経 験をもとに，高血圧症の病態と予後について述べ
た。その要約上，今後の研究課題について私見を 述べると次のよらになる。

（1）高血王の基礎疾患の頻度は，研究対象集団 による差が大さい、久山町一般住民剖検例中の 2 次性高血王の頻度は3.8\%と推定された。

（2）腎血管性高血王症と原発性アルドステロン 症の各種鑑別手技を比較評価した。 $\mathrm{Naバランスを}$ 考慮して評価することの重要性と，われわれの基 準によるカプトプリル テストが高い診断能力を 示した成績を述べた。

（3）レーン アンシオテンシン系の病態生理学 的意義を考察した。本態性高血王におけるレニ ン アンシオテンシン系の成因的意義と心血管系 障害との関連に関しては，まだ不明確な点がきわ めて多いといわなければならぬ。

（4）急性の脱塩によつて血王の下がる本態性高 血圧症例は，立位歩行時に血王の下がりやすいこ とを認めた。

（5）尿中Na排泄の日周リズムは, 頂点位相の出 現が本態性高血王例では正常血王例より約 3 時間 早期に，原発性アルドステロン症とクッシング症 候群では 5〜6時間叔くれて出現することを述べ た. 
（6）境界域高血王の成因・病態生理は若年者々 壮年者で異なることを示す成績を述ぺた，前者に おいてのみ交感神経 副腎系の機能六進が認めら れた。

（7）糖疗病（酎糖能異常）を合併した高血圧の 予後は，非合併例に比べて明らかに不良であつた。 心血管障害と腎障害の発生が有意に高頻度である ことを述べた。

(8) 久山町研究における, 心血管病のリスク ファクターとしての高血压の意義と、リスクファ クターの時代的変遷を述べた. 近年脳卒中が有意 に減少して扣り，それには血压管理と生活ならび に医療環境の好転が寄与していると考えられた。 また本研究で得られた脳動脈, 大動脈, 冠動脈硬 化の促進因子としての高血王の意義を述へ，脳梗 塞と心筋梗塞のリスクファクターの相違を述べ た. 高血王は脳梗塞の重要なリスクファクターと なつていたが，心筋梗塞では有意の関与が認めら れなかつた。

（9）基礎疾患別にみた悪性高血圧（KW III-IV 群）の病態と予後について述べた。本態性高血圧 を基礎疾患とするすのではレニン フンジオテン シン系の関与が認められるが，慢性系球体腎炎に よるものではそれが認められなかつた。 また，維 持透析療法中のものを含めて 5 年生存率が $86.7 \%$ であつた。

（10）降王薬投与後早期に発症した心血管事故 について述べた。降王薬投与が脳梗塞や心筇梗塞 の発症, 腎障害の進行を助長する場合のあり得る ことについて注意を喚起した。

\section{0. 今後の研究課題}

最後にこれまでの研究を通じて，今後重要と 考えられる研究課題についての私見を述べた。

（1）本態性高血圧の細分類

本態性高血圧症は，均一な疾病集団ではないの でそそれを細分類するための臨床研究がとくに必 要である。

（2）慢性高血圧状態になるまでの過程の分析

高血王が確立すると, 観察される現象が高血圧 の成因に関連するるのか，結果現象であるかの判
断が困難となる，血圧調節に関与寸る因子は血压 の上昇によつて修飾される。したがつて，血圧上 昇前の状態あるいは上昇の過程をよく知る必要が ある.そのため, 小児科領域の研究が重要で, こ れは高血王の一次予防にもつながる.

（3）高血圧以外の心血管病のリスクファクター の解明

人種差, 地域差, 時代に上る変遷, 生活様式, 性差，年令差などを考慮したりスクファクターの 解明。これは心血管病の予防にとつて重要である だけでなく，成因の解明にも奇与すると考学る。

（4）合理的治療法の開発

一般療法 (非薬物的降王療法) の研究と, 可及 的に副作用が少なく心血管病の予防効果の大きい 降王薬の開発がのぞまれる。

（5）血圧測定法の客観化，標準化

自動血王計の開発, 測定条件の標準化など, 高 血圧症の地域別比較を行なら場合に重要な問題と なる。

共同研究者：格山幸志郎, 川崎晃一, 小野山薰, 上田 一雄, 江藤片尚, 激下信一, 上野道雄, 阿部功, 布井清 秀, 川副信行, 村谷博美, 土橋卓也, 富田雄二, ほ济高血 王, 脳䛻環, 堅, 㜍尿病, 久山町研究室の各位に深甚の謝 意を表する。

\section{文献}

1) Kumamoto $K$, et al: Renin response to upright posture in varying sodium balance in normal young Japanese men. Jpn Heart J 20 : 777, 1979.

2) Haber E, et al: Application of a radioimmunoassay for angiotensin $I$ to the physiological measurement of plasma renin activity in normal human subjects. J Clin Endocrinol Met 29: 1949, 1969.

3）中龺田澄子, 他：Radioimmunoassay kitによる 血等フルドステロン㴗度の测定一NIH抗血清を 用いた従来の方法との比較検討。臨床病理 24 ： $163,1976$.

4) 中转田澄子, 他：125Iアルドステロンキット（AIdosterone-RIA Kit）による血 アルドステロン 惯度の測定. 臨床成人病 $10: 2025,1980$ 。

5）上野道雄，他：多变量回縞分析の臨床医学への応 用一cosinor法によるrhythm分析。医学のあゆみ $113: 851,1980$.

6) Halberg F, et al: Autorhythmometry-proce- 
dures for physiologic self-measurements and their analysis. Physiology Teacher 1: 1, 1972.

7）上野道雄，他：原発性アルドステロン症の術前・ 術後に扎忊る尿中電解質, アルドステロン排泄, 17OHCSのcircadian rhythmの分析. 高血圧 2 : 39, 1979.

8）川副信行, 他：Cushing症候群における尿中アル ドステロンおよびNa排泄のcircadianrhythm, 日 内分泌誌 $57: 1284,1981$.

9）河野雄平，他：若年および壮年の境界域高血生に

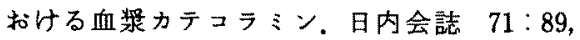
1982.

10) Kawano $Y$, et al: Elevated plasma catecholamines without alteration in cardiovascular responsiveness in young men with borderline hypertension. Amer Heart J 104 : 1351, 1982.

11) Omae $T$ and Ueda $K$ : Hypertension and other risk factors in cardiovascular diseases-The
Hisayama study. Proc. two symposia, 8th Ascian-Pacific Congress of Cardiology, APCS No. 29, Excerpta Medica, 1983, p12.

12）佐渡島省三，他：一地域住民（久山町）の10年間 疫学調査に括ける剖検例の動脈硬化ならびに動脈 硬化性疾患阅する研究。福岡医誌 $65: 701$, 1974.

13) Sadoshima $S$, et al : Cerebral and aortic atherosclerosis in Hisayama, Japan. Atherosclerosis $36: 117,1980$.

14）屋宮央哉，他：久山町住民における冠動脈硬化と その促進因子. 第24回日本老年医学会総会発表(昭 和58年10月，京都市).

15) Fujishima $M$, et al: Cerebrospinal fluid lactate and pyruvate concentrations in patients with malignant hypertension. J Neurol 231 : 71, 1984.

16）占部由利，他：悪性高血压症の治療早期に発症し た多発性脳梗塞の 1 例。内科 $51: 369,1983$. 